Bull. Fac. Agric., Cairo Univ.,57 (2007):57-72.

\title{
RESPONSE OF VALENCIA ORANGE TREES GROWN IN SANDY SOIL TO TREATMENTS WITH BIOZEM, AMCOTONE , CA-EDTA AND ZN-EDTA AND THEIR EFFECT ON FRUIT QUALITY, REGREENING AND YIELD
}

(Received:13.7.2006)

BY

\author{
S.A.G. El- Saida \\ Citriculture Department, Horticulture Research. Institute, Agriculture Research Center, Giza
}

\begin{abstract}
This investigation was conducted in (2004 - 2005 and 2005-2006) seasons on 14- year- old Valencia orange ( Citrus sinensis L.) trees grafted on sour orange (Citrus aurantium L.) rootstock and spaced at $5 \times 5 \mathrm{~m}$ in a private orchard near El -Sadat city (sandy soil ). It aimed at studying the effect of foliar application with active ingredients, micro elements and fitohormonas biologicamente actives( Biozem )and Naphthyl acetic acid +1- naphtyyl acetamide (Amcotone) and their combination with CaEDTA, Zn-EDTA on tree yield productivity, fruit set, fruitting percentage, regreening, leaf area, leaf chlorophyll's and mineral content . Different treatments significantly affected leaf area. Biozem plus CaEDTA plus Zn-EDTA and Biozem plus Zn-EDTA were more effective in this respect. It is quite evident that leaf chlorophyll's content was significantly affected by these treatments .Some fluctuations have been noticed, as , Biozem plus Zn-EDTA gave a high effect in both seasons . Tree yield and productivity, fruit set and fruitting percentage were significantly affected by Biozem plus Ca-EDTA and Zn-EDTA or Biozem plus Zn-EDTA compared to the other treatments which gave the lowest value of fruit June drop and fruit preharvest drop . All calcium treatments significantly increased fruit removal pull force and firmness as compared to control . Fruit weight, fruit volume, fruit removal force, fruit shape, peel thickness, juice percentage and juice density were significantly influenced by the different treatments . Fruit weight, fruit volume, peel thickness and juice density were significantly affected by Biozem application alone or as a combined treatment with Zn-EDTA and Ca-EDTA. Amcotone plus CaEDTA gave the highest fruit juice percentage if compared to other treatments . Biozem plus CaEDTA and Zn-EDTA caused increased juice T.S.S. and juice density. While Amcotone plus Zn-EDTA recorded the highest T.S.S/ Acid ratio . Moreover, Amcotone alone significantly increased total sugar content in juice. Whereas Biozem plus Zn- EDTA increased ascorbic acid content (V.C). Moreover, all calcium treatments increased rind chlorophylls and decreased rind catotenoids . Biozem and Amcotone plus Ca-EDAT or Zn-EDTA increased leaf mineral content of $\mathrm{N}, \mathrm{P}, \mathrm{K}, \mathrm{Ca}, \mathrm{Mg}, \mathrm{Zn}, \mathrm{Fe}$ and $\mathrm{Mn}$ leaf content . This may improve tree yield and leaf chlorophyll's content .

The highest yield / tree and the best fruit quality of Valencia orange trees was obtained when the trees were sprayed with Biozem at $1.5 \mathrm{ml} / \mathrm{L}+\mathrm{Ca}-$ EDTA $1.4 \mathrm{gm} / \mathrm{L}+\mathrm{Zn}$-EDTA $1.5 \mathrm{mg} / \mathrm{L}$ (on 20 of March, first of July and mid of August)
\end{abstract}

Key words : Amoctone, biozem, ca- EDTA , coloring , fruit firmness, , fruit pull force, , fruit quality, , regreening valencia orange, $\mathrm{Zn}$ EDTA.

\section{INTRODUCTION}

Valencia orange is an important fresh fruit for exports and local markets and for making juice during summer season, however the trees tend to have poor crop under sandy soil conditions .

In citrus, massive abscission of developing ovaries, generally occurs shortly after anthesis . Cultural practices were tied to overcome this problem mostly including application of exogenous growth regulators $\left(\mathrm{GA}_{3}\right)$ and some foliar nutrients applications (like Zn ) (Talon et al.,2000). In addition, Arora and Yamdagni (1986) found that compound fertilizer which contain $\mathrm{Zn}$ at $0.5 \%$ increased the number of flowers / shoot, the percentage of hermaphrodite flowers, fruit set and final fruit retention. Giffillan et al. ( 1974) and Simit (1990) mentioned that $\mathrm{GA}_{3}$ significantly affects tree yield and fruit quality. Sharaf (1990) suggested that $\mathrm{ZnSO}_{4}$ resulted in the highest 
fruit-set and significantly increased the number of flowers formed on bearing shoots . Desai et al., (1991) increased leaf chlorophyll content, average fruit weight and T.S.S and vitamin C concentration of fruit .Also, Navel orange fruiting was increased by $20-30 \%$ after spraying with $\mathrm{GA}_{3}+\mathrm{Zn}+\mathrm{Mn}$ (Blanco et al., 1994).

Zinc is one of the most important micronutrient required for normal plant nutrition (Follett et al.,1981), Zinc is essential for the synthesis of indol acetic acid (IAA) ( Mengel and Kirkby,1978, Follett et al., 1981 and Faust, 1989). Also, it plays the same important role in the biosyntheses of chlorophyll precursors and photosynthesis (Clarkson and Hanson , 1980 and Yagodin , 1984 , a)

In addition, auxin may either delay or stimulate this process and ethylene acts as a trigger agent responsible for the expression of cell wall degrading enzyme (Zacarias and Stead 2000). Ferguson (1988) considered the association of $\mathrm{Ca}^{2+}$-EDTA spraying with plant growth substance in the following facts , : (a) There is an extra cellular role for $\mathrm{Ca}^{2+}$-EDTA spray in plant tissue, (b) There is an intracellular role for $\mathrm{Ca}^{2+}$-EDTA spray in plant tissues , where $\mathrm{Ca}^{2+}$-EDTA spray may act as a secondary messenger transfusing external stimuli into immediate and long-term metabolic events, which might involve both fundamental growth responses to specialized environmental stimuli ,( c) There is tightly controlled regulation of $\mathrm{Ca}^{2+}-$ EDTA spray concentration and fluxes in the cell .This control is essential for normal cell function, and any malfunction of this regulation will lead to disruption of growth and cellular damage or death .
Therefore, the aim of this study is to assess the effect of Biozem, Amcotone , Ca-EDTA and Zn-EDTA separately or combined on yield , fruit quality and leaf mineral contents of Valencia orange trees, under sandy soil conditions .

\section{MATERIALS AND METHODS}

This investigation was carried out through two seasons of (2004 - 2005 and 2005-2006)in a private orchard near El-Sadat City (sandy soil ) grafted on 14- year old Valencia orange trees ( Citrus sinensis L.) on sour orange (Citrus aurantium L.) rootstock . The trees were planted at $5 \times 5 \mathrm{~m}$ and drip irrigation system was used . All trees (one hundred and eight) were selected and grouped to a nine treatments with four replicates including three trees for each treatment in a complete randomized block design

The following treatments were applied on 20 March, first July and mid of August

$\mathrm{T}_{1}$ : Biozem at $1.5 \mathrm{ml} / \mathrm{L}$.

$\mathrm{T}_{2}$ : Biozem at $1.5 \mathrm{ml} / \mathrm{L}+\mathrm{Ca}-\mathrm{EDTA}$ at $1.4 \mathrm{gm} /$ $\mathrm{L}$

$\mathrm{T}_{3}$ : Biozem at $1.5 \mathrm{ml} / \mathrm{L} \mathrm{Zn-EDTA}$ at $1.5 \mathrm{mg} /$ $\mathrm{L}$

$\mathrm{T}_{4}$ : Biozem at $1.5 \mathrm{ml} / \mathrm{L}+\mathrm{Ca}-\mathrm{EDTA}$ at $1.4 \mathrm{gm} / \mathrm{L}$ + Zn-EDTA at $1.5 \mathrm{mg} / \mathrm{L}$.

$\mathrm{T}_{5}$ : Amcotone at $0.75 \mathrm{gm} / \mathrm{L}$.

$\mathrm{T}_{6}$ : Amcotone at $0.75 \mathrm{gm} / \mathrm{L}+\mathrm{Ca}-\mathrm{EDTA}$ at 1.4 $\mathrm{gm} / \mathrm{L}$.

$\mathrm{T}_{7}$ : Amcotone at $0.75 \mathrm{gm} / \mathrm{L}+\mathrm{Zn}-\mathrm{EDTA}$ at 1.5 $\mathrm{mg} / \mathrm{L}$.

$\mathrm{T}_{8}$ : Amcotone at $0.75 \mathrm{gm} / \mathrm{L}+\mathrm{Ca}-\mathrm{EDTA}$ at 1.4 $\mathrm{gm} / \mathrm{L}+\mathrm{Zn}-\mathrm{EDTA}$ at $1.5 \mathrm{mg} / \mathrm{L}$.

$\mathrm{T}_{9}$ : Control (water sprayerd ).

Table (1) a- Biozyme contents :

\begin{tabular}{|l|l|}
\hline $\begin{array}{l}\text { (active ingredients ( micro elements (eq. a 19.34 gr / } \\
\text { lt 1.86 ) }\end{array}$ & $\begin{array}{l}\text { Fierro 0.49 \%, Zinc 0.34 \%, Manganeso 0.012 \%, } \\
\text { Magnesio 0.14\%, Boro 0.30\%, Azufre 0.44 \% - }\end{array}$ \\
\hline (Fitohormonas biologicamente actives 78.87) & $\begin{array}{l}\text { Giberelines 32.2 ppm ( eq a 0.031 gr/it) Acide } \\
\text { indolacetico 32.2 ppm (eq. a 0.031 gr/ lt), zeatine 83.2 } \\
\text { ppm ( eq. a 0.083 gr /lt) }\end{array}$ \\
\hline Inert ingredients & (Diluyentes y acondicionadores 19.27) \\
\hline
\end{tabular}

b- Amcotone contents :

\begin{tabular}{|c|c|}
\hline Plant growth regulato & Thtolo romi \\
\hline $\begin{array}{l}\text { Chemical Name - Napn } \\
\text { Composition }\end{array}$ & \\
\hline NAA & $045 \%$ \\
\hline NAAM & $1.25 \%$ \\
\hline ADUVANTS+ INFPTS & $98.3 \%$ \\
\hline TOTAL & $100 \%$ \\
\hline
\end{tabular}




\section{The following aspects were studied}

\subsection{Flowering, yield and fruit quality}

flowering, fruit set $\%$,fruit June drop $\%$,fruit preharvest drop \% and removed fruit \% ( fruit set was estimated by selecting six secondary branches around each tree in February. At the blooming time ( Late March ) flowering twigs on each selected branch were tagged and the total number of flowers per twig was recorded. The number of setting fruits was counted at weekly intervals till the middle of November and fruiting \% was calculated by dividing the number of fruits in mid November by the total number of flowers in late March x 100 .

B- Yield: at mid of April fruit yield was recorded annually as a number and weight per tree (kg.) .

$\mathrm{C}$-Sample of 10 mature fruits per each replicate was selected in the $4^{\text {Th }}$ week of February to determine fruit physical properties The average fruit weight $(\mathrm{gm})$, fruit volume , fruit removal force $\mathrm{L} / \mathrm{Cm}^{3}$ (F R F) (according to El -Zeftawi and Dinsey 1983), fruit firmness (by means of Meangness Taglor pressurs tester), fruit shape $\mathrm{L} / \mathrm{D}$ length and diameter in $\mathrm{cm}$ (by Vernier caliper length to diameter ratio), peel thickness was measured by Vernier caliper and juice percentage and juice density. Chlorophylls( $\mathrm{a} \& \mathrm{~b})$ and carotenoid pigments in the rind of fruit were extracted in three dates ( 15 April , 1 May and 15 May) as Wettstein 's formula (1957), measured at 662.644 and $440 \mathrm{Mu}$ wave length using spectrophtometer (Backman ,Du 6400) and calculated according to the following equations:

- Chl. a $=9.784 \times$ E, $662-0.99 \times$ E $644=$ $\mathrm{mg} / \mathrm{L}$.

- $\quad$ Chl. b $=21.426 \times$ E, $644-4.65 \times$ E $662=$ $\mathrm{mg} / \mathrm{L}$.

- $\quad$ Carotenoids $=4.695 \times$ E $440-0.264(a+b)$ $=\mathrm{mg} / \mathrm{L}$.

- Where E: optical density at the wave length indicated .

Fruit chemical properties : Total soluble solids (T.S.S) determined by using Carl Zeiss hand referactometer, total acidity as gms of unhydrus citric acid and Vitamin $\mathrm{C}$ as $\mathrm{mg}$ ascorbic acid were determined and estimated per $\mathrm{mg} / 100 \mathrm{ml}$ juice. Fruit juice was measured according to A.O.A.C. (1965), Moreover ,T.S.S/acid ratio was also estimated and total sugars were determined colorimetrically as gm . glucose per $100 \mathrm{mls}$ of juice according to the methods described by Thomas and Dutcher (1924) .

\subsection{Leaf area and leaf mineral contents}

On March of both seasons , twenty spring nonfruiting shoots from all over the outer circumference of each treated tree were labeled in leaf samples. From each replicate, a sample of about 60 leaves was taken in the first week of October ( each year ) for the chemical analysis and calculated leaf area as Bremner and Taha (1966) The collected leaf samples were washed with tap water, rinsed three times with distilled water and then oven dried at $70 \circ \mathrm{C}$ to a constant weight . Leaf dried materials were ground in a stainless steel rotary knife with a mill 20 mesh . The dried ground sample was digested with sulphuric acid and hydrogen peroxide according to Evenhuis and De Waard (1980). Suitable aliquots were taken for the determination of $\mathrm{N}, \mathrm{P}, \mathrm{K}, \mathrm{Ca}, \mathrm{Mg}, \mathrm{Fe}, \mathrm{Zn}$ and $\mathrm{Mn}$

a- Total nitrogen percentages in dry leaves are determined by using the microkjeldahal method as described by A.O.A.C. (1965) .

b- Phosphorus was determined by using ammonium venedate method as described by Chapman and Pratt (1961)

c- Potassium was determined by flame photometer according to Brown and Lilleland (1946) .

d- Calcium and magnesium were determined according to the wet aching method technique as reported by Koch and Meekin (1924), by using atomic absorption spectorphotometer .

e-Zinc was determined according to Chapman (1961) directly in the original solution by using atomic absorption spectorphotometer .

$\mathrm{f}-\mathrm{Fe}$ and $\mathrm{Mn}$ _were determined according to Evenhuis and De Waard 1980 )

g- Determination of photosynthetic pigments in leaves : Chlorophyll $a$ and $b$ were exteracted from fresh leaves by grinding them in a mortar with $85 \%$ aqueous acetone. The pigments were filtered through funnel No, G4 , then the filtrate was made up to a known volume with $85 \%$ acetone. The optical density of the filtrate was determined using Carl -Zeiss spectrocolorimeter at the wave length of 662 , 644 and $440 \mathrm{~nm}$ for chlorophyll $\mathrm{a}$ and $\mathrm{b}$, respectively .The concentrations of chlorophyll $a$ and $b$ were calculated by means of Wettstein's formula (Wettstein , 1957).

Experimental design was a complete randomized block design according to Snedecor and Cochran (1967 ). The averages were compared using L.S.D. parameter .

\section{RESULTS AND DISCUSSIONS}

Data obtained on the influence of Biozem , Amcotone , Ca- EDTA and Zn-EDTA on Valencia orange trees are as follows. 


\subsection{Leaf area}

Data presented in ( Table 1 ) reveal that, Biozem plus $\mathrm{Zn}$ or Biozem plus $\mathrm{Zn}$ and $\mathrm{Ca}$ or Amcotone plus $\mathrm{Zn}$ treatments significantly increased Valencia orange leaf area compared to the other treatments in both seasons . Biozem plus $\mathrm{Zn}$ and $\mathrm{Ca}$ treatment showed the highest effect ( 21.89 and $22.94 \mathrm{~cm}^{2}$ ) in both seasons respectively. However the control treatment had the lowest values $\left(17.18\right.$ and $17.63 \mathrm{~cm}^{2}$ ), respectively in both seasons .

These results are in line with those obtained by Desai et. al., (1991); Nawab Ali et al., (1992) and Ouyang (1993) on some citrus species. They reported that Zinc enhanced leaf area. Singh and Sharma (2000) working on Citrus, reported that all the micronutrients play a vital role in several biochemical processes in plant system. Sayed et al., (2004 b) reported that GA3 and micronutrient foliar spray increased leaf area of Valencia orange trees .

\section{2. leaf chlorophyllcontent}

From the data presented in (Table 1) it is quite obvious that Valencia orange leaf chlorophyll ( a \&b) content increased when compared to the control in both seasons. It is clear that chlorophyll -a significantly increased in both seasons compared with the control by Biozem plus Zn-EDTA spraying, Biozem plus Ca-EDTA plus Zn-EDTA , Amcotone plus Zn-EDTA and Amcotone plus Ca-EDTA plus Zn-EDTA. Also chlorophyll-b significantly increased in the first season compared with the control by spraying of Biozem plus Zn-EDTA and Biozem plus $\mathrm{Ca}$ EDTA plus Zn-EDTA respectively, while in the second season chlorophyll-b was significantly increased by spraying Biozem , Biozem plus $\mathrm{Zn}-$ EDTA , Biozem plus Zn-EDTA , Biozem plus Ca-EDTA plus Zn-EDTA , Amcotone plus ZnEDTA and Amcotone plus Ca- EDTA plus ZnEDTA. The best treatment in this regard was obtained by spraying Biozem plus Zn-EDTA in both seasons 8.960 and 8.983 as chlorophyll-a and 5.728 and 5.799 as chlorophyll -b ) respectively . The increase in chlorophyll $-b$ may be due to the increase in chlorophyll-a because chlorophyll- a is a precursor for the synthesis of chlorophyll -b (Smith and French , 1963 and Castelfranco and Beale, 1983 ). These results are in harmony with those obtained by Nawab Ali et al., (1992); Ouyang (1993 ) on some citrus species. They reported a positive enhancement of Zinc on all growth parameters and leaf pigments. El Saida (1996) reported the positive enhancement of Zinc on all leaf pigments . Abd El Rahman (2002) found that calcium treatments increased rind chlorophyll as compared with the control . Sayed et al.,( 2004 b ) suggested that $\mathrm{GA}_{3}$ and micronutrients increased chlorophyll ( $\mathrm{a}$ and $\mathrm{b}$ ) content in leaf tissues. Hamed (2005) found that Zinc treatments gradually increase in chlorophyll $a, b$ in leaves of Valencia orange trees .

\subsection{Leaf mineral composition (Macronutrients) 3.3.1. Leaf nitrogen content}

Table (1) shows that all treatments of Biozem, Amcotone, Zn-EDTA and Ca- EDTA and their combinations caused a high significant increase in leaf $\mathrm{N} \%$ of Valencia orange trees compared to the control during the two seasons. Biozem plus $\mathrm{Zn}$ - EDTA recorded the highest values (2.58 and $2.59 \%$ ) in both seasons a respectively. These result are in agreement with the findings of $\mathrm{El}$ Saida (1996 , 2001), Abd El-Rahman et al., 2001 \& Abd El Rahman 2003) who reported that Zinc sulfate alone and its combination(with Ca-EDTA and Biozem increased $\mathrm{N}$ in Navel orange leaves . Sayed et al.,(2004b)suggested that $\mathrm{GA}_{3}$ and micronutrients increased leaf mineral content .

\subsubsection{Leaf phosphorus content}

Concerning leaf $\mathrm{P} \%$ (Table 1) the obtained data show that all treatments resulted in a slight significant increase in leaf $\mathrm{P} \%$ as compared to the control during the two seasons. Nevertheless ,Biozem plus Ca- EDTA plus Zn EDTA and Amcotone plus Ca EDTA were more effective ( $0.205,0.272$ and $0.269,0.266 \%$ ) respectively in the two seasons. Similar trend was found by El Saida (1996, 2001 ), Abd El Rahman et al., 2001\& Abd El Rahman 2003 and Sayed et al., (2004 b) who found that Zinc sulfate a lone and its combination ( with Ca-EDTA and Biozem and Biostimulant $+\mathrm{GA}_{3}+\mathrm{Zn}$ ) treatments increased leaf content of $\mathrm{P} \%$ compared with the control .

\subsubsection{Leaf Potassium content}

Referring to the effect of Biozem , Amcotone , Ca-EDTA , Zn-EDTA and their combinations on the Valencia orange trees, data presented in (Table 1) reveal that all treatments increased leaf $-\mathrm{K}$ content when compared to the control in both seasons. Biozem plus Zn-EDTA, Amcotone plus Ca- EDTA and Amcotone plus Ca- EDTA and Amcotone plus Zn-EDTA clearly increased leaf $\mathrm{K}$ content $(1.60,1.56,1.48$ and $1.28,1.36,1.77$ $\%$ ) respectively for the two seasons, while Amcotone alone had the lowest effect ( 1.00 and $1.02 \%$ ), respectively in the two seasons .

These result are in agreement with that reported by El-Shazly (1981) who reported foliar application of chelated Zinc significantly increased leaf potassium content of Valencia 


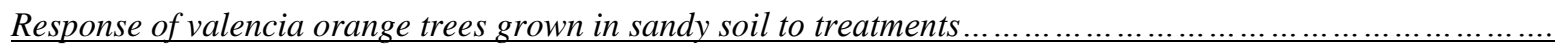

Table (1): Effect of some treatments on Leaf area $\mathrm{C} \mathrm{m}^{2}$, Chlorophylls (A,B) and mineral composition of Valencia orange trees during 2004-2005 and 2005-2006.

\begin{tabular}{|c|c|c|c|c|c|c|c|c|c|c|c|}
\hline \multicolumn{12}{|c|}{ First season, 2004-2005 } \\
\hline Treat & Leaf area $\mathrm{C} \mathrm{m}^{2}$ & Chlorophyll(A) & Chlorophyll(B) & $\mathbf{N} \%$ & $\mathbf{P} \%$ & K \% & Ca \% & Mg \% & Zn ppm & Fe ppm & Mn ppm \\
\hline $\mathbf{T}_{1}$ & 18.39 & $\mathbf{7 . 4 7 8}$ & 5.296 & 2.42 & 0.164 & 1.02 & 4.87 & 0.447 & 46 & 101 & 48 \\
\hline $\mathbf{T}_{2}$ & 19.22 & 7.628 & 5.349 & 2.45 & 0.170 & 1.03 & 4.81 & 0.423 & 55 & 105 & 69 \\
\hline $\mathbf{T}_{3}$ & 21.26 & 8.960 & 5.728 & 2.58 & 0.155 & 1.60 & 4.43 & 0.410 & 45 & 112 & 54 \\
\hline $\mathbf{T}_{4}$ & 21.89 & 8.21 & 5.651 & 2.53 & 0.205 & 1.22 & 5.15 & 0.480 & 50 & 105 & 54 \\
\hline $\mathbf{T}_{5}$ & 18.22 & 7.211 & 5.200 & 2.17 & 0.146 & 1.00 & 4.44 & 0.409 & 41 & 100 & 39 \\
\hline $\mathbf{T}_{6}$ & 18.59 & 7.300 & 5.279 & 2.41 & 0.272 & 1.56 & 4.39 & 0.400 & 69 & 101 & 72 \\
\hline $\mathbf{T}_{7}$ & 19.62 & 7.809 & 5.359 & 2.31 & 0.180 & 1.48 & 4.56 & 0.430 & 44 & 110 & 56 \\
\hline $\mathbf{T}_{8}$ & 19.80 & 7.984 & 5.364 & 2.39 & 0.159 & $\mathbf{1 . 1 5}$ & 5.12 & 0.470 & 46 & 108 & 65 \\
\hline $\mathbf{T}_{9}$ & 17.18 & 6.902 & 5.155 & 1.87 & 0.100 & 0.85 & 3.13 & 0.360 & 34 & 97 & 28 \\
\hline L.S.D 5\% & 2.19 & 0.88 & 0.25 & $\mathbf{0 . 3 0}$ & 0.074 & 0.32 & 0.87 & 0.051 & 15.05 & 6.45 & 17.63 \\
\hline \multicolumn{12}{|c|}{ Second season, 2005 -2006 } \\
\hline Treat & Leaf area $\mathrm{C} \mathrm{m}^{2}$ & Chlorophyll(A) & Chlorophyll(B) & $\mathbf{N} \%$ & $\mathbf{P} \%$ & K \% & Ca \% & $\mathrm{Mg} \%$ & Zn ppm & Fe ppm & Mn ppm \\
\hline $\mathbf{T}_{1}$ & 19.26 & 7.487 & 5.488 & 2.48 & 0.174 & 1.06 & 4.98 & 0.457 & 47 & 100 & 50 \\
\hline $\mathbf{T}_{2}$ & 18.80 & 7.710 & 5.481 & 2.58 & 0.180 & 1.09 & 5.76 & 0.480 & 56 & 104 & 70 \\
\hline $\mathbf{T}_{3}$ & 22.35 & 8.983 & 5.799 & 2.59 & 0.158 & 1.28 & 4.63 & 0.427 & 46 & 111 & 52 \\
\hline $\mathbf{T}_{4}$ & 22.94 & 8.580 & 5.789 & 2.54 & 0.269 & 1.04 & 5.08 & 0.500 & 55 & 105 & 54 \\
\hline $\mathbf{T}_{5}$ & 18.49 & 7.260 & 5.222 & 2.24 & 0.150 & 1.02 & 4.53 & 0.414 & 42 & 100 & 41 \\
\hline$T_{6}$ & 18.26 & 7.316 & 5.300 & 2.38 & 0.266 & 1.36 & 4.49 & 0.437 & 60 & 105 & 74 \\
\hline $\mathbf{T}_{7}$ & 21.39 & 7.786 & 5.499 & 2.33 & 0.170 & 1.77 & 4.58 & 0.440 & 45 & 108 & 56 \\
\hline $\mathbf{T}_{8}$ & 19.44 & 8.168 & 5.596 & 2.53 & 0.161 & 1.19 & 5.42 & 0.453 & 48 & 104 & 68 \\
\hline $\mathbf{T}_{9}$ & 17.63 & 6.896 & 5.201 & 1.95 & 0.120 & 0.94 & 3.30 & 0.353 & 30 & 95 & 33 \\
\hline L.S.D 5\% & 2.28 & 0.88 & 0.25 & 0.28 & 0.076 & 0.18 & 1.06 & 0.063 & 12.9 & 6.88 & 15.91 \\
\hline
\end{tabular}

$\mathrm{T}_{1} \quad$ Biozem at $1.5 \mathrm{ml} / \mathrm{L}$ ( on 20 March, first July and mid August )

$T_{2} \quad$ Biozem at $1.5 \mathrm{ml} / \mathrm{L}+\mathrm{Ca}$ - EDTA $1.4 \mathrm{gm} / \mathrm{L}$ ( on 20 March, first July and mid August )

$\begin{array}{ll}\mathrm{T}_{2} & \text { Biozem at } 1.5 \mathrm{ml} / \mathrm{L}+\mathrm{Zn}-\text { EDTA } 1.5 \mathrm{mg} / \mathrm{L} \text { ( on } 20 \text { March, first July and mid August ) }\end{array}$

$\mathrm{T}_{4} \quad$ Biozem at $1.5 \mathrm{ml} / \mathrm{L}+\mathrm{Ca}-$ EDTA $1.4 \mathrm{gm} / \mathrm{L}+\mathrm{Zn}-$ EDTA $1.5 \mathrm{mg} / \mathrm{L}$ (on 20 March, first July and mid August)

$T_{5} \quad$ Amcotone at $0.75 \mathrm{gm} / \mathrm{L}$ ( on 20 March, first July and mid August )

$\mathrm{T}_{6} \quad$ Amcotone at $0.75 \mathrm{gm} / \mathrm{L}+\mathrm{Ca}-$ EDTA $1.4 \mathrm{gm} / \mathrm{L}$ ( on 20 March, first July and mid August )

$\mathrm{T}_{7} \quad$ Amcotone at $0.75 \mathrm{gm} / \mathrm{L}+\mathrm{Zn}-$ EDTA $1.5 \mathrm{mg} / \mathrm{L}$ ( on 20 March, first July and mid August )

$\mathrm{T}_{8} \quad$ Amcotone at $0.75 \mathrm{gm} / \mathrm{L}+\mathrm{Ca}-$ EDTA $1.4 \mathrm{gm} / \mathrm{L}+\mathrm{Zn}-$ EDTA $1.5 \mathrm{mg} / \mathrm{L}$ (on $20 \mathrm{March}$, first July and mid August)

T 9 Control 
orange trees. El-Saida(2001) found that Zinc sulfate and its combinations with Biozem and GA3 increased leaf content of potassium than the control. Sayed et al.,(2004 b) found that $\mathrm{GA}_{3}$ and micronutrients increased leaf mineral content . Hamed (2005) reported that the highest values of $\mathrm{K}$ concentration were detected in the leaves of the trees treated with the highest level of $\mathrm{Zn}$.

\subsubsection{Leaf calcium}

Concerning leaf $\mathrm{Ca}$ content, it is clear from the data presented in (Table 1) that Biozem plus CaEDTA plus Zn- EDTA and Amcotone plus CaEDTA plus Zn- EDTA in the first season and Biozem plus Ca- EDTA, Biozem plus Ca-EDTA plus ZnEDTA and Amcotone plus Ca- EDTA plus ZnEDTA in the second season had a highly significant increase leaf $\mathrm{Ca}$ content of Valencia orange compared to the other treatment ( 5.15 and $5.12 \%$ ) in the first season, ( 5.76, 5.08 and $5.42 \%)$ in the second season, respectively. The obtained results are confirmed by the finding of Mohsen et al., (1990) on Balady oranges who reported that $\mathrm{Zn}$ foliar application tended to increase leaf- Ca content. ElSaida (1996 ), (2001) found that Zn So4 + Biozem increased leaf content of $\mathrm{Ca}$ compared with other treatments . Sayed et al.,( 2004 b ) reported that $\mathrm{GA}_{3}$ and micronutrients increased leaf mineral content .

\subsubsection{Leaf magnesium content}

Concerning leaf $\mathrm{Mg}$ content, the data in (Table 1) show that all treatments increased $\mathrm{Mg}$ content in both seasons . The highest value was recorded by Biozem plus Ca- EDTA and Amcotone plus Ca-EDTA plus Zn-EDTA ( 0.480 and $0.470 \%$ ) in the first season, receptively, but in the second season it was by Biozem plus Ca- EDTA and Biozem plus Ca- EDTA plus Zn-EDTA ( 0.480 and $0.500 \%$ ), respectively . These results are in agreement with those mentioned by Meyer et al., (1966), as amino acids and Zinc foliar application enhanced IAA synthesis in the cells of plant which stimulate cations absorbtion. Sayed et al., (2004 b) Reported that the best results were obtained from foliar sprays of Biostumlant + GA3 + $\mathrm{K} 40 \%+\mathrm{Zn} 14 \%$ treatment .

\subsection{Micronutrients}

\subsection{Leaf Zinc content}

From the data obtained in both seasons ( Table 1 ) it could be concluded that Biozem plus Zn-EDTA and Amcotone plus Zn- EDTA gave highly significant increase in leaf $\mathrm{Zn}$ content in the first season (69 and $50 \mathrm{ppm}$ ) respectively, but Biozem plus Zn-EDTA, Biozem plus Ca- EDTA plus ZnEDTA and Amcotone plus Zn-EDTA gave highly significant increments $(60,55$ and $56 \mathrm{ppm})$ respectively in second season . However, Biozem plus $\mathrm{Ca}$-EDTA and Amcotone treatments slightly increased it compared to the control (44 and 41 ppm and 45 and $42 \mathrm{ppm}$ ) in the first and second seasons, respectively. These results are in line with those obtained by Mohsen et al., (1990) who found that the highest leaf $\mathrm{Zn}$ content was obtained by spraying Balady orange with $1 \%$ followed by $0.5 \mathrm{Zn} \mathrm{So}_{4}$. Swietlik and Laduke (1991) El- Saida (2001)and Abd El Rhman(2003) reported that Zinc sulfate alone and its combination with Ca- EDTA and Biozem increase $\mathrm{Zn}$ in Navel orange leaves .

\subsubsection{Leaf iron content}

Regarding leaf $-\mathrm{Fe}$ content, data in (Table 1) show that Biozem plus Zn- EDTA and Amcotone plus Zn-EDTA gave the highest values (112 and $110 \mathrm{ppm}$ in first season and 111 and $108 \mathrm{ppm}$ in the second season, respectively). Also, the data indicated that leaf Fe content increased compared with the control in all treatments .

This result is in harmony with those obtained by Mohsen et al.,1990 who mentioned that $\mathrm{Zn}$ foliar application on Balady orange caused a correction of leaf chlorosis . El- Saida (2001) reported that $\mathrm{Zn} \mathrm{So}_{4}+$ Biozem increased leaf content of $\mathrm{Fe}$ as a combined or Biozem alone. Abo El-Komsan et al ., (2003 ) on mandarin reported that foliar application of GA3 ; $\mathrm{Zn}$ and micronutrients has a positive effect on leaf mineral content .

\section{3..4.3. Leaf manganese content}

Generally, from the data obtained in both seasons ( Table 1), it could be noticed that leaf $\mathrm{Mn}$ content was increased by all treatments seasons. The highest values were obtained by foliar sprays of Biozem plus Ca- EDTA , Amcotone plus Ca- EDTA and Amcotone plus Ca- EDTA plus Zn- EDTA ( $69,72,65$ and 70, $74,68 \mathrm{ppm}$ ), respectively in both seasons. These findings are in agreement with those obtained by El- Saida (2001) who found that Zn So4 + Biozem treatments increased leaf content of $\mathrm{Mn}$ combined treatment or alone. Abd El- Rahman (2001) reported that Zinc sulfate alone (at $5 \mathrm{~g} / \mathrm{L}$ ) and its combination ( with Ca-EDTA at $0.5 \mathrm{~g} / \mathrm{L}$ Biozem at $1.5 \mathrm{~m} / \mathrm{L}$ and gibberellic acid at $15 \mathrm{ppm}$ ) increased $\mathrm{N}, \mathrm{Ca}, \mathrm{Fe}, \mathrm{Zn}$ and $\mathrm{Mn}$ in Navel orange leaves . El- Baz (2003) found that foliar sprays of both Zinc ( $\mathrm{Zn}$ sulphate soluation at 250 and 500 ppm zn ) increased significantly the concentration of $\mathrm{N}, \mathrm{K}, \mathrm{Mn}$ and $\mathrm{Zn}$ in Balady mandarin leaves of spring flush .

\subsubsection{Fruit set percentage}

Data concerning fruit set percentage recorded in both seasons are presented in (Table 2). It is clear that fruit set percentage increased 
significantly in treated trees compared with the control in both seasons, except foliar sprays of Biozem alone and Amcotone plus Ca-EDTA in the first season and Biozem alone and Amcotone alone in the second season which was insignificantly increased.The best treatments in this regard were foliar sprays of Biozem plus Ca-EDTA plus Zn-EDTA , Biozem plus Zn- EDTA and Amcotone plus CaEDTA plus Zn-EDTA in both seasons (37.81,37.33 and $37.01 \%)$ in the first season and ( $38.02,37.88$ and $37.22 \%$ ) in the second season), respectively

\subsubsection{Fruit Juice drop percentage}

According to the data presented in ( Table 2 ) fruit June drop decreased by all treatments in both seasons and the best result was obtained by Biozem plus Ca- EDTA plus Zn- EDTA in both seasons $(90.09,90.31$ and $90.89 \%)$ in the first season and $(90.00,90.11$ and $90.50 \%)$ in the second season

\subsubsection{Preharvest fruit drop percentage}

It is clear from the data presented in (Table 2 ) that foliar sprays of Biozem plus - Ca - EDTA plus Zn- EDTA , Biozem plus Zn- EDTA and Amcotone plus Ca- EDTA plus Zn- EDTA treatments significantly decreased the preharvest fruit drop percentage in both seasons $(1.21,1.49$, 1.82 and $1.13,1.26,1.59 \%$ ), respectively . The data also indicated that preharvest fruit drop percentage was the lowest under all treated trees compared to the control .

\subsubsection{Fruit remained percentage}

Data presented in (Table 2) indicated that fruit remained percentage increased by all treatments in both seasons. Data showed that the highest values were obtained by foliar sprays of Biozem plus Ca-EDTA plus Zn-EDTA , Biozem plus ZnEDTA and Amcotone plus Ca-EDTA plus ZnEDTA treatments in first and second seasons $(2.66,2.51,2.43$ and $2.71,2.64,2.50 \%)$ respectively .

\subsection{Tree yield}

Valencia orange tree yield as number or weight per tree significantly increased by the applied treatments ( Table 2 ).

\subsubsection{Yield by kgs per tree}

It is evident from the data presented in Table (2) that yield by $\mathrm{kgs}$ per tree significantly increased in all treatments in the first season except foliar sprays of Amcotone alone and Amcotone plus Ca- EDTA, the increase was insignificant. The most convenient treatments were foliar sprays of Biozem plus Ca- EDTA plus Zn- EDTA , Amcotone plus Zn- EDTA and Amcotone plus Ca- EDTA plus Zn- EDTA (72.13, 73.70 and $69.41 \mathrm{~kg}$ ), respectively. In the second season the average yields as weight per tree was significantly increased by all foliar spray treatments compared with the control. The best values were by Biozem plus Ca- EDTA, Biozem plus - Zn- EDTA and Biozem plus Ca- EDTA plus Zn - EDTA ( $90.37,92.04$ and $85.34 \mathrm{~kg}$ ), respectively .

\section{5.2.Yield as number per tree}

It is clear from the data presented in Table( 2) that foliar sprays of Biozem plus Zn- EDTA and Biozem plus Zn- EDTA plus Ca- EDTA gave the highest number of fruit per tree ( 425and 445), respectively. Also, the average number of fruits per tree increased significantly by all treatments in the first season except foliar sprays of Biozem alone and Amcotone plus Ca- EDTA . Average yield as number per tree in the second season increased significantly in all treatments except in foliar sprays of Biozem alone, Amcotone alone and Amcotone plus Ca- EDTA which increased insignificantly. The best results in this regard were obtained by foliar sprays of Biozem plus $\mathrm{Zn}$ EDTA and Biozem plus Zn- EDTA plus CaEDTA ( 473 and 783 ) , respectively .The obtained results are in accordance with those obtained by Stino et al (1981) who found that NAA decreased soluble pectin in the abscission zone of the pedicel of Leconte pear. Sharaf (1990) on Balady orange, found that $\mathrm{Zn} \mathrm{So} 4$ increased fruit set, fruitting, and yield, and decrease fruit June drop, Sourour (2000), Perveen and Rehman (2000) on sweet orange .El-Azazi (2001), reported that potassium and calcium application had a great influence on fruit set efficiency and reducing pre- harvest fruit drop and El- Saida (2001) on Navel orange trees , found that zinc sulphate + Biozem or $\mathrm{GA}_{3}$ significantly increased fruit set percentage, had superior effect on the reduction of June drop percent, reduction of preharvest fruit drop percent subsequently the highest yield was obtained. Abd El- Rahman (2003), ElBaz (2003) on Balady mandarin trees, reported that the highest yield was obtained by spraying $\mathrm{Zn}(250 \mathrm{ppm})$, the increase occurred in both fruit number per tree and their fruit weight .Sayed et al., ( 2004 a ) found that calcium nitrate and $\mathrm{GA}_{3}$ on grapefruit trees increased fruit yield per tree . Hamed (2005) found significant and gradual increase in tree yield $(\mathrm{kg})$ and number of fruits per tree of Valencia orange with increasing $\mathrm{Zn}$ rate as foliar spraying .

\subsubsection{Fruit removal force $\mathrm{L} / \mathrm{Cm}^{3}$ ( FRF )}

It can be stated from the obtained data in (Table 2 ) that fruit removal force significantly increased in all treatments in both seasons, except the trees treated with Biozem alone or Amcotone alone. 
Table (2): Effect of some treatments on yield, fruit set \%, fruit drop (June and preharvest), fruit remand percentage and some fruit quality of Valencia orange trees during 2004 -2005and 20052006.

\begin{tabular}{|c|c|c|c|c|c|c|c|c|c|c|c|}
\hline \multicolumn{12}{|c|}{ First season, 2004-2005 } \\
\hline Treat. & $\begin{array}{c}\text { Yield weight / } \\
\text { tree }\end{array}$ & $\begin{array}{c}\text { Yield } \\
\text { No. / tree }\end{array}$ & $\begin{array}{l}\text { Fruit } \\
\text { set } \%\end{array}$ & $\begin{array}{c}\text { Fruit June } \\
\text { drop \% }\end{array}$ & $\begin{array}{r}\text { Preharvest } \\
\text { fruit drop \% }\end{array}$ & $\begin{array}{c}\text { Fruitting } \\
\text { percentage }\end{array}$ & $\begin{array}{c}\text { Fruit } \\
\text { weight(gm) }\end{array}$ & $\begin{array}{c}\text { Fruit } \\
\text { volume(ml) }\end{array}$ & $\begin{array}{c}\text { Fruit pull } \\
\text { force } L / \mathrm{cm}^{3}\end{array}$ & $\frac{\text { Firmness }}{\text { L/ 1inch }}$ & $\begin{array}{c}\text { Fruit shape } \\
\text { H/D } \\
\end{array}$ \\
\hline $\mathbf{T}_{1}$ & 66.98 & 331 & 35.20 & 92.77 & 3.20 & 2.22 & 201.90 & 207.03 & 42.77 & 15.81 & 1.09 \\
\hline $\mathbf{T}_{2}$ & 61.52 & 374 & 36.18 & 91.68 & 2.60 & 2.30 & 170.05 & 175.55 & 44.23 & 16.34 & 1.10 \\
\hline $\mathbf{T}_{3}$ & 68.65 & 425 & 37.33 & 90.31 & 1.49 & 2.51 & 166.42 & 170.53 & 45.81 & 17.25 & 1.05 \\
\hline $\mathbf{T}_{4}$ & 72.13 & 445 & 38.81 & 90.09 & 1.21 & 2.66 & 167.18 & 173.19 & 46.37 & 17.82 & 1.08 \\
\hline $\mathbf{T}_{5}$ & 50.17 & 326 & 35.03 & 92.91 & 3.33 & 2.19 & 153.89 & 160.02 & 41.68 & 15.69 & 1.06 \\
\hline $\mathbf{T}_{6}$ & 51.64 & 340 & 35.46 & 92.30 & 2.81 & 2.29 & 155.81 & 161.08 & 43.90 & 16.07 & 1.03 \\
\hline $\mathbf{T}_{7}$ & 73.70 & 380 & 36.74 & 91.18 & 2.07 & 2.40 & 196.69 & 201.50 & 44.76 & 16.88 & 1.13 \\
\hline $\mathbf{T}_{8}$ & 69.41 & 382 & 37.01 & 90.89 & 1.82 & 2.43 & 183.57 & 188.56 & 45.13 & 17.01 & 1.12 \\
\hline $\mathbf{T}_{9}$ & 43.4 & 310 & 34.10 & 93.01 & 3.69 & 2.03 & 142.42 & 147.23 & 40.48 & 14.26 & 1.01 \\
\hline L.S.D 5\% & 12.35 & 58.05 & 1.6 & 1.26 & 1.07 & 0.27 & 25.78 & 25.7 & 2.53 & 1.16 & 0.051 \\
\hline \multicolumn{12}{|c|}{ Second season, 2005-2006 } \\
\hline $\mathbf{T}_{1}$ & 69.98 & 385 & 35.81 & 92.35 & 3.04 & 2.26 & 185.81 & 190.77 & 43.01 & 16.05 & 1.09 \\
\hline $\mathbf{T}_{2}$ & 90.37 & 416 & 36.74 & 91.22 & 2.40 & 2.37 & 220.87 & 226.18 & 44.79 & 16.61 & 1.12 \\
\hline $\mathbf{T}_{3}$ & 92.04 & 473 & 37.88 & 90.11 & 1.26 & 2.66 & 211.03 & 216.04 & 46.38 & 17.50 & 1.14 \\
\hline $\mathbf{T}_{4}$ & 85.34 & 483 & 38.02 & 90.00 & 1.13 & 2.71 & 182.40 & 188.39 & 47.15 & 18.00 & 1.16 \\
\hline $\mathbf{T}_{5}$ & 60.98 & 351 & 35.38 & 92.41 & 3.24 & 2.21 & 173.73 & 179.88 & 42.66 & 15.92 & 1.06 \\
\hline$T_{6}$ & 65.56 & 358 & 36.30 & 92.04 & 2.52 & 2.32 & 185.42 & 189.66 & 44.00 & 16.35 & 1.07 \\
\hline $\mathbf{T}_{7}$ & 77.12 & 425 & 37.13 & 90.97 & 1.96 & 2.46 & 188.78 & 193.95 & 44.91 & 17.17 & 1.05 \\
\hline $\mathbf{T}_{8}$ & 73.82 & 425 & 37.22 & 90.0 & 1.59 & 2.50 & 177.93 & 182.79 & 45.75 & 17.31 & 1.13 \\
\hline $\mathbf{T}_{9}$ & 45.74 & 322 & 34.26 & 92.82 & 3.44 & 2.06 & 145.50 & 150.51 & 40.36 & 14.32 & 1.04 \\
\hline L.S.D $5 \%$ & 13.36 & 69.23 & 1.62 & 1.21 & 0.99 & 0.31 & 32.40 & 32.53 & 2.92 & 1.21 & 0.051 \\
\hline
\end{tabular}

$\mathrm{T}_{1} \quad$ Biozem at $1.5 \mathrm{ml} / \mathrm{L}$ ( at 20 March, first July and mid August )

$\mathrm{T}_{2} \quad$ Biozem at $1.5 \mathrm{ml} / \mathrm{L}+\mathrm{Ca}-$ EDTA $1.4 \mathrm{gm} / \mathrm{L}$ ( on 20 March, first July and mid August )

$\mathrm{T}_{3} \quad$ Biozem at $1.5 \mathrm{ml} / \mathrm{L}+\mathrm{Zn}-$ EDTA $1.5 \mathrm{mg} / \mathrm{L}$ ( on 20 March, first July and mid August )

$\mathrm{T}_{4}$ Biozem at $1.5 \mathrm{ml} / \mathrm{L}+\mathrm{Ca}-$ EDTA $1.4 \mathrm{gm} / \mathrm{L}+\mathrm{Zn}-$ EDTA $1.5 \mathrm{mg} / \mathrm{L}$ (on 20 March, first July and mid August)

$\mathrm{T}_{5} \quad$ Amcotone at $0.75 \mathrm{gm} / \mathrm{L}$ ( on 20 March, first July and mid August )

$\mathrm{T}_{6}$ Amcotone at $0.75 \mathrm{gm} / \mathrm{L}+\mathrm{Ca}-$ EDTA $1.4 \mathrm{gm} / \mathrm{L}$ ( on 20 March, first July and mid August )

$\mathrm{T}_{7} \quad$ Amcotone at $0.75 \mathrm{gm} / \mathrm{L}+\mathrm{Zn}-\mathrm{EDTA} 1.5 \mathrm{mg} / \mathrm{L}$ ( on 20 March, first July and mid August)

$\mathrm{T}_{8} \quad$ Amcotone at $0.75 \mathrm{gm} / \mathrm{L}+\mathrm{Ca}-$ EDTA $1.4 \mathrm{gm} / \mathrm{L}+\mathrm{Zn}-$ EDTA $1.5 \mathrm{mg} / \mathrm{L}$ (on 20 March, first July and mid August)

$\mathrm{T}_{9}$ Control 
tree at harvesting time. Naturally this will be

It is clear that fruit removal force significantly translated into final yield .

increased by all foliar spray treatments with calcium ( Biozem plus Ca-EDTA, Biozem plus Ca-EDTA plus Zn-EDTA , Amcotone plus Ca-EDTA , Amcotone plus Ca-EDTA plus Zn-EDTA) compared with the control in both seasons $(44.23,46.37,43.90,45.13$ and $44.79,47.15,44.00,45.75 \mathrm{~L} / \mathrm{cm}^{3}$ ), respectively . The highest values were obtained by Biozem plus Ca-EDTA plus Zn-EDTA, Biozem plus Zn-EDTA and Amcotone plus Ca- EDTA plus Zn-EDTA treatment in both seasons and were $(46.37,45.81$ , 45.13 and $\left.47.15,46.38,45.75 \mathrm{~L} / \mathrm{cm}^{3}\right)$, respectively

\subsubsection{Fruit firmness $L / 1$ inch $^{2}$}

From the data in ( Table 2 ) it is noticed that all calcium treatments resulted in a significantly increase in fruit firmness, it is clear that Biozem plus CaEDTA , Biozem plus Ca-EDTA plus Zn-EDTA , Amcotone plus Ca-EDTA and Amcotone plus CaEDTA plus Zn-EDTA significantly increased fruit in both seasons amounting to $(16.34,17.82,16.07$, 17.01 and $16.61,18.00,16.35,17.31 \mathrm{~L} / 1 \mathrm{inch}^{2}$ ) respectively. The best treatment in this regard was Biozem plus Ca-EDTA plus Zn-EDTA (17.82, $18.00 \mathrm{~L} / 1 \mathrm{inch}^{2}$ ) in both seasons respectively.

Effects of calcium may be attributed to delaying the abscission process by separation layer as divisions in paranchyma cells with simple vesicular conjunction , this increased pull force, Grieson and Tucker (1983 ), mentioned that Ca- EDTA spray, markedly reduced the cell wall break- down and fruit senescences, therefore it reduced pre- harvest fruit drop chance . El-Shafey et al., (2002), reported that calcium has an important role in maintaining in cell wall structure and membrane intergrity by the inter action of calcium with pectic acid in cell wall to form calcium pectate. Moreover, they added that calcium causes a reduction or delay in cell wall break down, and this effect causes a delay in fruit softing. Sayed et al., (2004 a) stated that calcium nitrate showed a remarkable increase in thickness of both union zone and pedicel by 154.6 and $10.6 \%$, respectively, also showed well brought- up degree of vascular connection and enough amounts of cell adhesion in the union zone comparing with the untreated plants .

To sum up, to obtain the maximum fruitting percentage, presence of Biozem or Amcotone plus Ca- EDTA plus Zn- EDTA or plus Zn- EDTA alone is necessary. This may be attributed to that , Biozem and Zn-EDTA increase levels of IAA, Amcotone and Ca-EDTA delays fruit by delays abscission process and increase fruit removal force. This regime will give the maximum number of fruits on

\subsubsection{Fruit physical and chemical properties Fruit weight}

Data in (Table 2) show clear that fruit weight increased by all treatment in both seasons, but significant increases were obtained by foliar spray of Biozem, Acotone plus Zn- EDTA, Amcotone plus Ca- EDTA plus Zn- EDTA and Biozem plus Zn- EDTA $(201.90,196.69,183.57$ and 170.05 $\mathrm{g}$ ) in the first season, respectively, and in the second season to foliar spray with Biozem alone (220.87, 211.03 , 188.78 and $185.81 \mathrm{gm} \mathrm{),}$ respectively .

\section{Fruit volume}

It can be stated from the obtained data in ( Table 2 ) that fruit volume increased by all applications in both seasons. It is clear that the highest values were obtained by foliar sprays of Biozem , Amcotone plus Zn- EDTA and Amcotone plus Ca- EDTA plus Zn- EDTA $(207.03,201.50$ and $188.56 \mathrm{ml})$, respectively in the first season, but in the second season by foliar sprays with Biozem plus Ca-EDTA, Biozem plus Zn- EDTA and Amcotone plus Zn- EDTA (226.18 , 216.04 and $193.95 \mathrm{ml}$.), respectively .

\section{Fruit shape ( H/ D)}

Data regarding fruit shape $(\mathrm{H} / \mathrm{D}$ ratio ) presented in (Table 2), show that, all treatments have changed fruit shape to be oblong, and also indicated that most treatment was significantly increased H/ D ratio compared control except in foliar sprays with Biozem plus Zn- EDTA , Amcotone and Amcotone plus Ca- EDTA. In second season however, data the showed that fruit shape index increased significantly compared with the control by foliar sprays of Biozem or Amcotone plus Ca- EDTA, Zn- EDTA and Biozem plus CaEDTA.

\section{Peel thickness}

Table 2 shows that all treatments gave a significant increment in peel thickness compared with the control in both seasons. It is clear from data that the highest peel thickness was obtained by foliar sprays of Biozem plus Ca- EDTA plus Zn-EDTA $(0.56$ and $0.58 \mathrm{~cm})$ in the first and the second seasons, respectively.

\section{Juice percentage}

According to the data in (Table 2 ) average Juice percentage increased in all treatments compared with the control in both seasons. All treatments significantly increased it compared to the control, except foliar sprays with Amcotone alone whereas the increment were insignificant in the first season, by foliar sprays with Biozem 
plus Ca- EDTA, Biozem plus Ca-EDTA plus Zn- treatments with Biozem were superior over all the EDTA and Amcotone alone in the second season . treatments with Amcotone. It is evident that the It could be observed that Amcotone foliar average total sugars \% increment for foliar application in combination with of Ca - EDTA application of Biozem plus Ca-EDTA, Biozem plus gave the highest increment in fruit juice Zn-EDTA, Biozem and Biozem plus Ca-EDTA plus percentage (56.54 and 50.55\%), respectively in the Zn-EDTA (8.72. 8.51.8.30 and $8.23 \%$ ) in first first and the second seasons.

\section{Juice density}

season, respectively compared with the control, whereas in the second season the total sugars \% was

Data in ( Table 2 ) indicated that juice density enhanced by folior spray of Biozem plus Ca-EDTA, increased by all treatments compared with the control Biozem, Biozem plus Ca-EDTA plus Zn-EDTA and . The best results were obtained by foliar sprays of Biozem plus Zn- EDAT (8093. 8089 . 8.82 . and Biozem plus Zn- EDTA, Biozem plus Ca - EDTA 8.81\%) compared with the control respectively. The plus Zn- EDTA and Amcotone plus Zn- EDTA plus best results were obtained by foliar spray of Biozem Zn- EDTA (1.08, 1.07, 1.06 and 1.06, $1.09,1.08$ plus Ca -EDTA (8.72 and 8.93\%), respectively in $\mathrm{gm} / \mathrm{mL}$ ) in first and second seasons, respectively .

\section{Total soluble solid percentage}

It could be stated from the obtained data in (Table 3 ) that all treatments increased significantly the percentage of total soluble solids of fruit juice as compared with the control . Biozem plus $\mathrm{Ca}$ - EDTA plus Zn- EDTA gave the best results in the first and the second seasons (12.87 and $12.93 \%)$, respectively .

\section{Acidity percentage}

Data in the ( Table 3 ) clearly show that the total acidity percentage increased significantly compared by the control and by foliar sprays of Biozem alone, Biozem plus Ca-EDTA , Biozem plus $\mathrm{Zn}$-EDTA and Biozem plus Ca-EDTA plus $\mathrm{Zn}$ EDTA in first and second seasons $(1.19,1.13,1.18$, 1.16 and $1.22,1.20,1.21,1.23 \%$ ) respectively . The highest values were by foliar sprays of Biozem in both season (1.19 and 1.22), respectively, and by foliar sprays of Amcotone plus Zn-EDTA in first season and Amcotone plus Ca-EDTA plus Zn-EDTA in second season (1.02 and 1.02 ) respectively .

\section{T.SS / acid ratio}

It is clear from the data in Table 3 that Amcotone plus Zn- EDTA showed superiority over all other treatments (11.500) in the first season . In the second season, Amcotone plus Ca - EDTA plus Zn- EDTA was superior over all other treatments (11.4618) including the control. Also, it was observed that the foliar sprays of Amcotone plus Ca - EDTA or plus Zn- EDTA or in combination in creased T.S.S.\% acid ratio as compared with all treatment . The increment in this ratio came as a result of reducing acidity and increasing T.S.S which definitely affect T.S.S/ acid ratio.

\section{Total sugar percentage}

It is obvious from the data presented in (Table 3) that all treatments increased total sugar $\%$ as compared with the control in both seasons. Maximum increment was obtained when Biozem was applied with $\mathrm{Ca}-$ EDAT or Zn-ETDA alone and with them both. Statistical analysis of the present data proved that all the both seasons .

\section{Vitamin C}

Data regarding Vitamin $\mathrm{C}$ content in fruit juice $(\mathrm{mg} / 100 \mathrm{ml}$ juice ) presented in ( Table 3 ) show that all treatments significantly increased Vitamin $\mathrm{C}$ except Amcotone compared with the control in both seasons. The best result was obtained by foliar sprays of Biozem plus Zn-EDTA Biozem and Biozem plus $\mathrm{Ca}$-EDTA treatments as the increased Vitamin $\mathrm{C}$ was significantly higher than other treatments (49.27.48.90.40.30 and 49.93 $49.10 .48 .53 \mathrm{mg} / 100 \mathrm{ml}$ juice ), respectively in both seasons .

\subsection{Rind pigments \\ 3.6.1.First sample ( mid April ) a. Chlorophyll-a}

Concerning the effect of the all treatments on chlorophyll -a content of fruit rind in (Table 3) the results clearly show that the amount of chlorophyll-a was increased if compared with the control. The highest values of chlorophyll-a content in fruit rind were recorded by Biozem plus $\mathrm{Ca}-$ EDTA plus Zn-EDTA, Biozem plus $\mathrm{Zn}-$ EDTA, Biozem plus Ca-EDTA, and Biozem $(0.0719,0.0718,0.0702,0.0628$ and 0.0800 , $0.0758,0.0743,0.0734 \mathrm{mgm} / 100 \mathrm{gms}$ ) of fresh weight, respectively in both seasons. It is clear from the data that chlorophyll-a content was significantly increased by all treatments compared with the control in both seasons except foliar sprays of Amcotone alone which insignificantly increased chlorophyll-a content in both seasons. It is obvious from the previous data that zinc application increased chlorophyll-a content in fruit rind. This increment could be due to its role in the synthesis of chlorophyll precursor protoporpho billingen (PPB), which is the precursor of the chlorophyll (Yagodin, 1984,b) . 
Response of valencia orange trees grown in sandy soil to treatments.....

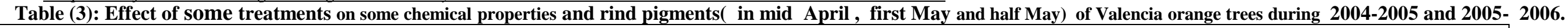

\begin{tabular}{|c|c|c|c|c|c|c|c|c|c|c|c|c|c|c|}
\hline \multicolumn{15}{|c|}{$\begin{array}{ll} & \text { First season, 2004-2005 }\end{array}$} \\
\hline \multirow{2}{*}{ Treat. } & \multirow[b]{2}{*}{$\begin{array}{r}. S . S \\
\%\end{array}$} & \multirow{2}{*}{$\begin{array}{c}\text { Acidity } \\
\%\end{array}$} & \multirow{2}{*}{$\begin{array}{c}\text { T.S.S / } \\
\text { Acidity } \\
\text { ratio }\end{array}$} & \multirow{2}{*}{$\begin{array}{l}\text { Total } \\
\text { sugars } \\
\%\end{array}$} & \multirow{2}{*}{$\begin{array}{c}\text { V.C mg / } \\
100 \mathrm{ml} \\
\text { juice }\end{array}$} & \multicolumn{3}{|c|}{ Rind pigments in mid April } & \multicolumn{3}{|c|}{ Rind pigments in first May } & \multicolumn{3}{|c|}{ Rind pigments in half May } \\
\hline & & & & & & Chl.(A) & Chl.(B) & $\begin{array}{l}\text { carotonoi } \\
\text { ds }\end{array}$ & Chl.(A) & Chl.(B) & $\begin{array}{l}\text { carotonoi } \\
\text { ds }\end{array}$ & Chl.(A) & Chl.(B) & $\begin{array}{l}\text { carotono } \\
\text { ids }\end{array}$ \\
\hline $\mathbf{T}_{1}$ & 12.60 & 1.19 & 10.588 & 8.30 & 48.90 & 0.0628 & 1.7148 & 8.0192 & 0.3803 & 2.2408 & 6.8052 & $\mathbf{0 . 5 5 5 3}$ & 2.3778 & 6.3522 \\
\hline $\mathbf{T}_{2}$ & 12.30 & 1.13 & 10.884 & 8.72 & 48.30 & 0.0702 & 1.7303 & 6.9220 & 0.3822 & 2.2563 & 5.7080 & 0.5572 & 2.3933 & 5.255 \\
\hline $\mathbf{T}_{3}$ & 12.23 & 1.18 & 10.364 & 8.51 & 49.27 & 0.0718 & 1.7341 & 8.0657 & 0.3838 & 2.2601 & 6.8517 & 0.5588 & 2.3971 & 6.3987 \\
\hline $\mathbf{T}_{4}$ & 12.87 & 1.16 & 10.501 & 8.23 & 45.03 & 0.0719 & 1.8732 & 7.6680 & 0.3839 & 2.3992 & 6.4540 & 0.5589 & 2.5362 & 6.001 \\
\hline $\mathbf{T}_{5}$ & 11.60 & 1.06 & 10.943 & 7.88 & 38.19 & 0.0519 & 1.1687 & 7.8571 & 0.3639 & 1.6947 & 6.6431 & 0.5389 & 1.8317 & 6.1901 \\
\hline$T_{6}$ & 11.77 & 1.06 & 11.103 & 7.27 & 46.20 & 0.0572 & 1.3655 & 5.9443 & 0.3692 & 1.8915 & 4.7303 & 0.5442 & 2.0285 & 4.2773 \\
\hline $\mathbf{T}_{7}$ & 11.73 & 1.02 & 11.500 & 7.54 & 44.53 & 0.0602 & 1.6826 & 7.9999 & 0.3722 & 2.2086 & 6.7859 & 0.5472 & 2.3456 & 6.3329 \\
\hline $\mathbf{T}_{8}$ & 11.57 & 1.07 & 10.812 & 7.64 & 44.92 & 0.0604 & 1.7124 & 6.6769 & 0.3724 & 2.2384 & 5.4629 & 0.5474 & 2.3754 & 5.0099 \\
\hline $\mathbf{T}_{9}$ & 10.24 & 1.00 & 10.24 & 4.66 & 33.50 & 0.0449 & 0.9175 & 7.8165 & 0.3569 & 1.4435 & 6.6025 & 0.5319 & 1.5805 & 6.1495 \\
\hline L.S.D 5\% & 1.13 & 0.08 & 0.54 & 1.75 & 6.78 & 0.0113 & 0.4027 & 0.9099 & 0.01269 & 0.4491 & 0.9970 & 0.0126 & 0.3838 & 0.9971 \\
\hline \multicolumn{15}{|c|}{ Second season, $2005-2006$} \\
\hline $\mathbf{T}_{1}$ & 12.17 & 1.22 & 10.467 & 8.89 & 49.10 & 0.0734 & 1.8491 & 8.1282 & 0.4304 & 2.4651 & 6.8072 & 0.4524 & 2.7001 & 6.3452 \\
\hline $\mathbf{T}_{2}$ & 12.67 & 1.20 & 10.558 & 8.93 & 48.53 & 0.0743 & 1.9213 & 6.7045 & 0.4313 & 2.5373 & 5.3835 & 0.4533 & 2.7723 & 4.9215 \\
\hline $\mathbf{T}_{3}$ & 12.69 & 1.21 & 10.487 & 8.81 & 49.93 & 0.0758 & 1.9228 & 8.1303 & 0.4328 & 2.5388 & 6.8093 & 0.4548 & 2.7738 & 6.3473 \\
\hline $\mathbf{T}_{4}$ & 12.93 & 1.23 & 10.500 & 8.82 & 47.87 & 0.0800 & 1.9749 & 7.5918 & 0.4370 & 2.5909 & 6.2708 & 0.4590 & 2.8259 & 5.8088 \\
\hline $\mathbf{T}_{5}$ & 11.62 & 1.07 & 10.859 & 7.96 & 39.25 & 0.0558 & 1.3049 & 7.7412 & 0.4128 & 1.9209 & 6.4202 & 0.4348 & 2.1559 & 5.9582 \\
\hline$T_{6}$ & 11.97 & 1.08 & 11.083 & 7.89 & 46.47 & 0.0563 & 1.5005 & 5.9695 & 0.4133 & 2.1165 & 4.6485 & 0.4353 & 2.3515 & 4.1865 \\
\hline $\mathbf{T}_{7}$ & 11.93 & 1.09 & 10.945 & 7.72 & 44.90 & 0.0701 & 1.7249 & 7.8474 & 0.4271 & 2.3409 & 6.5264 & 0.4491 & 2.5759 & 6.0644 \\
\hline $\mathbf{T}_{8}$ & 11.69 & 1.02 & 11.461 & 7.89 & 45.33 & 0.0726 & 1.7956 & 6.5794 & 0.4296 & 2.4116 & 5.2584 & 0.4516 & 2.6466 & 4.7964 \\
\hline $\mathbf{T}_{9}$ & 10.29 & 1.01 & 10.188 & 5.13 & 34.97 & 0.0416 & 0.9811 & 7.6127 & 0.3986 & 1.5971 & 6.2917 & 0.4206 & 1.8321 & 5.8297 \\
\hline L.S.D 5\% & 1.14 & 0.09 & 0.65 & 1.63 & 6.43 & 0.0159 & 0.4203 & 0.9201 & 0.0180 & 0.4670 & 1.0155 & 0.1804 & 0.4670 & 1.0156 \\
\hline
\end{tabular}

$\mathrm{T}_{1} \quad$ Biozem at $1.5 \mathrm{ml} / \mathrm{L}$ ( at 20 March, first July and mid August )

$\mathrm{T}_{2}$ Biozem at $1.5 \mathrm{ml} / \mathrm{L}+\mathrm{Ca}-$ EDTA 1.4 gm / L ( on 20 March, first July and mid August )

$T_{3}$ Biozem at $1.5 \mathrm{ml} / \mathrm{L}+\mathrm{Zn}$ - EDTA $1.5 \mathrm{mg} / \mathrm{L}$ ( on 20 March, first July and mid August )

$\mathrm{T}_{4} \quad$ Biozem at $1.5 \mathrm{ml} / \mathrm{L}+\mathrm{Ca}-$ EDTA $1.4 \mathrm{gm} / \mathrm{L}+\mathrm{Zn}-$ EDTA $1.5 \mathrm{mg} / \mathrm{L}$ (on 20 March, first July and mid August)

$\mathrm{T}_{5}$ Amcotone at $0.75 \mathrm{gm} / \mathrm{L}$ ( on 20 March, first July and mid August )

T 6 Amcotone at $0.75 \mathrm{gm} / \mathrm{L}+\mathrm{Ca}-$ EDTA $1.4 \mathrm{gm} / \mathrm{L}$ ( on 20 March, first July and mid August )

$T_{7}$ Amcotone at $0.75 \mathrm{gm} / \mathrm{L}+\mathrm{Zn}-$ EDTA $1.5 \mathrm{mg} / \mathrm{L}$ ( on 20 March, first July and mid August )

$T_{8} \quad$ Amcotone at $0.75 \mathrm{gm} / \mathrm{L}+\mathrm{Ca}-$ EDTA $1.4 \mathrm{gm} / \mathrm{L}+\mathrm{Zn}-$ EDTA $1.5 \mathrm{mg} / \mathrm{L}$ (on $20 \mathrm{March}$, first July and mid August)

T9 Control 


\section{b. Chlorophyll-b}

The present results showed that, there was a considerable similarity between the results of chlorophyll-a and b. It is clear from the data in (Table 3 ) that chlorophyll-b significantly increased in first and second seasons compared with the control by all treatments except by foliar spray of Amcotone which insignificantly increased it. The best results were obtained from foliar sprays of Biozem plus Ca-EDTA plus $\mathrm{Zn}$ EDTA, Biozem plus Zn- EDTA, Biozem plus CaEDTA and Biozem treatments as the increased in chlorophyll-b content was significantly higher $(1.8732,1.7341,1.7303,1.7148$ and $1.97 \mathrm{ug}$, $1.9228,1.9213,1.8491 \mathrm{mgm} / 100 \mathrm{gm}$ fresh weight ) than the other treatments in both seasons, respectively .

The increase in chlorophyll-b content in fruit rind of fruits treated with Zinc as compared with the control could be due to the influence of Zinc treatment on increasing the fruit rind content of chlorophyll-a , as both chlorophyll-a and chlorophyll-b could be converted to each other, and chlorophyll-a is the immediate precursor of chlorophyll-b (Castelfranco and Beale, 1983) .

\section{c. Carotenoids}

Table 3 shows that the average carotenoids insignificantly increased by foliar sprays of Biozem, Biozem plus Zn-EDTA , Amcotone and Amcotone plus Zn- EDTA (8.0192, 8.0657, $7.8571,7.999$ and $8.1282,8.1303,7.7412,7.8474$ $\mathrm{mgm} / 100 \mathrm{gm}$ ) of fresh weight compared with control in both seasons, respectively. On the other hand, foliar spray of $\mathrm{Ca}$-EDTA plus Biozem or plus Amcotone significantly or insignificantly decreased average carotenoids compared with the control in both seasons .It is evident from the data that average carotenoids insignificantly decreased for foliar sprays of Biozem plus Ca- EDTA and Biozem plus Ca- EDTA plus Zn-EDTA (6.9220, 7.6680 and $6.7045,7.918 \mathrm{mgm} / 100 \mathrm{mg}$ ) of fresh weight compared with control, respectively in both seasons . Data obviously indicate that carotenoids were significantly decreased by foliar sprays of Amcotone plus Ca-EDTA and Amcotone plus Ca-EDTA plus Zn-EDTA (5.9443 , 6.6769 and 5.9695, $6.5794 \mathrm{mgm} / 100 \mathrm{gm}$ ) of fresh weight compared with control in both seasons respectively .

\subsubsection{Second and third samples ( first May and half May )}

Concerning rind chlorophyll $-\mathrm{a}$, chlorophyll-b and carotenoids in both samples and in both seasons, it could be noticed that all calcium treatments caused an increased in rind chlorophyll (a \&b) and showed a decrease in carotenoids ,this mean that calcium increased regreening of fruit rind in maturity stage .

\section{a. Chlorophyll- a}

It is clear from the data in (Table 3) that the highest values of chlorophyll-a content in fruit rind were recorded by Biozem plus Ca-EDTA plus Zn-EDTA (0.3839 and $0.5589 \mathrm{mgm} / 100 \mathrm{gm})$ of fresh weight in both samples and in first season and $(0.4370$ and $0.4590 \mathrm{mgm} / 100 \mathrm{gm})$ in second season respectively compared with the control .

\section{b. Chlorophyll-b}

It is obvious from data presented in ( Table 3) that all calcium treatments increased chlorophyll$\mathrm{b}$ in both seasons and in both samples. Foliar spray of Biozem plus Ca- EDTA plus Zn-EDTA gave the highest values of chlorophyll-b (2.3992 and $2.5362 \mathrm{mgm} / 100 \mathrm{gm}$ ) of fresh weight in both samples and in first season and ( 2.5909 and $2.8259 \mathrm{mgm} / 100 \mathrm{gm}$ ) in second season respectively compared with the control .

\section{c. Carotenoids}

Data presented in ( Table 3) indicate that the lowest values were obtained by foliar sprays of Amcotone plus Ca-EDTA were 4.7303 and 4.2773 $\mathrm{mgm} / 100 \mathrm{gm}$ of fresh weight in both samples and in first season and 4.6485 and $4.1865 \mathrm{mgm} /$ $100 \mathrm{gm}$ in the second season respectively compared with the control.

These findings are partially in harmony with those obtained by Miller et al., (1940) who stated that during orange maturation there was a loss of chorophylls accompanied with an increase in carotenoids . Khadr et al. (1978) decided that Washington Navel orange when sprayed with $\mathrm{Zn}$ $\mathrm{So}_{4}$ causes an increase in fruit weight, fruit peel thickness and juice weight. El- Kassas et al., ( 1987 ), found that Zinc improved both physical and chemical fruit quality of Valencia orange trees .Njaroge et al. (1988 a and b) concluded that calcium caused an increase in rind chlorophyll's and a decrease in ring corotenoids. These may be, attributed to the role of calcium in delaying or reducing ripening and senescence. Desai et al. (1991), on sweet orange trees and Ouyang (1993), on Shaddock, orange and satsuma mandarin, suggested that zinc application increases fruit weight, ascorbic acid content of fruit juice, total sugars El-Saida (1996) mentioned that, the application of $\mathrm{Zn} \quad \mathrm{SO}_{4}$ or $\mathrm{GA}_{3}$ significantly increased fruit size, peel thickness . El-Saida (2001) found that both $\mathrm{Zn} \mathrm{So}_{4}$ plus Biozem or GA3 resulted in a high percentage of T.S.S , T.S.S/ Acid ratio and a good rind colour. Also. El-Azaze (2001) obtained that Ca-EDTA Spray application as protective in reducing the plant 
senescence and fruit ripening, much calcium would be disadvantageous in that it might inhibit cell enlargement and calcium chelate foliar consider by spraying a good protective agents for reducing fruit crack at harvest time and improved Navel orange fruit weight, Size and firmness Kanonich et al. (2000) and El- Saida (2001) found that foliar sprays of naphthalene acetic acid increased Juice $\%$ and acidity of kinnow mandarin. Kononich et al., ( 2000) and Ibraheim et al., (2001) suggested that NAA ( $400 \mathrm{ppm}$ ) treatment increased T.S.S and acidity .Abd-El Rahman (2002) found that calcium treatments increased rind chlorophyll and decrease rind corotenoids . El- Shafey et al., (2002) reported that calcium concentrations ( 48 and $126 \mathrm{ppm}$ ) at all application dates increased fruit pull force. ElBaz (2003) reported that, foliar zinc improved the quality ( Fruit weight, Fruit juice, T.S.S\% and Vitamin C ) of Balady mandarin trees . El-Saida (2001) and Abd El- Rahman (2003 ) found that, fruit weight, fruit size, fruit dimensions, peel thickness were significantly affected by $\mathrm{Zn} \mathrm{SO} 4$ and their combination Ca- EDTA, GA3 and Biozem, also significantly increased fruit juice weight, T.S.S\%, T.S.S\% acid ratio in Navel orange. Sayed et al., (2004b) reported that foliar sprays of Zinc $14 \%$ at $2.9 \mathrm{~g} / \mathrm{L}$ on Valencia orange increased fruit weight fruit dimensions, peel thickness, Juice percentage , total soluble solids \% . Sayed et al., (2004 a) found that calcium nitrate and $\mathrm{GA}_{3}$ on grape fruit trees improved the physical and chemical fruit properties, e. g. fruit weight, size, peel thickness, juice $\%$, T.S.S $\%$ acidity $\%$, T.S.S / acidity ratio, total sugar, vitamin C. Hamed (2005) indicated that, a significant and gradually increases in total sugars , Vit C , total acidity and total soluble solids were obtained by the fruit of Valencia orange trees with increasing $\mathrm{Zn}$ foliar application .

From the aforementioned results in this study, it was observed that foliar spray of Biozem plus Zn-EDTA plus Ca-EDTA increased of leaf area and chlorophylls of leaves. This improved fruit set , fruitting and reduce June drop percentage. Also this treatments gave the highest peel thickness, fruit removal force and firmness, which reflected on raising the yield .

It could be generally concluded that foliar spray with Biozem at $1.5 \mathrm{ml} / \mathrm{L}+\mathrm{Ca}$-EDTA 1.4 $\mathrm{gm} / \mathrm{L}+\mathrm{Zn}$-EDTA $1.5 \mathrm{mg} / \mathrm{L}$ (on 20 March, first July and mid August ) on Valencia orange trees , obtained the highest yield / tree and the best fruit quality .

\section{EFERENCES}

Abd-El-Rahman .A.M. ,(2002): Influence of calcium and ethrel treatments on degreening and fruit quality of Valencia orange . ( Hort. Res. Inst. Agric. Res Center Egypt ) Anmals of agric. Sci., Moshtohor. Vol. 40(2) : 1159 1170 .

Abd El-Rahman , A.M. (2003) . Effects of some nutrients and growth substances application on fruiting level of Phosphorus and Zinc application on broad bean (Vicia faba ) grown on calcareous soil . Res. Bull., Agric., Cairo Univ., 55 : 385-400

Abd- El-Rahman .A.M. , El-Saida S. A. G. and M. Abd- Sadek, S.D. (2001) : Effect of potassium and calcium treatments on yield and fruit quality of navel orange . Alex. Sci. Exch., Vol. 22 No. 3 , pp 203-219.

Abo El-Komsan, E.E. Hegab M.Y. and A. Found A. (2003): Response of Balady orange trees to foliar application of some nutrients and citric acid. The $2^{\text {nd }}$ Conference of Agric. And Biological, Res. Divis. G. Agric. Res, NRC- 1 (1) PP : $73-90$.

A.O.A.C. ( 1965) : Official methods of Analysis of the Association of Official Agriculture Chemists .10th Ed ., Published by the A.O.A.C Washington, D.C.

Arora R. K. and Yamdagni R. (1986) : Effects of different doses of nitrogen and zinc sprays on flowering, fruit set and final fruit retention in Sweet Lime(C.Limettioides Tanaka). Haryana Agricultural University Journal of Research , 16 (3) 233-239. (Hort. Abst. Vol. 57: 1969.

Blanco M., Nieves N. ,Gonzalez J.L. , Borroto C.G. , Escalona M., Acosto J.F. , Perez R. and Gonzalez A. (1994 ): Analysis of internal and external control factors of fruit set in Washington Navel . Centro- Agricola., 21:2 , 38-50.

Bremner R. E. and Taha M. A. (1966) : Studies on potato agronomy, J. Agric . Sci 66, 241252.

Brown J.D. and Lilleland O. (1946): Rapid determination of potassium and sodium in plant material and soil extracts by flam photometry. Proc. Amer. Soc. Hort. Sci ., vol. 48:341-436

Castel Franco, P.A. and Beale,. S.I. (1983): Chlorophyll biosynthesis : recent advance and areas of current interest. Ann. Rev. Plant Physiol., 34: 241- 278.

Chapman, H. D. (1961) :The status of present criteria for the diagnosis of nutrient conditions 
in citrus. In plant analysis and fertilizer problems. Amer. Inst . Bio, Sci pull Washington vol. 3 pp 75- 106

Chapman H.D. and Pratt P.F. (1961) : Methods of analysis for soils, plant and water. University of California , Division of Agric Science

Clarkson D.T. and Hanson J.B. (1980 ): The mineral nutrition of higher plants . Ann Rev . plant physiol. , $31: 239-298$.

Desai U. T. , Choudhari M.S., , Shirsath ans Kale , S.N. (1991) : Studies on the effect of foliar applications of micro- nutrients on nutrients in mosambi sweet orange . Maharashtra Journal of Horticulture 5(2) $29-31$-( Hort . Abst. Vol. 64 : 1418 ).

El-Azazi A.M. (2001 ): Some physiological studies on Citrus .M. .Sc. Thesis, Fac. Agric ., Cairo Univ., .

El-Baz E.E.T. ( 2003 ) . Effect of foliar spliar sprays of zinc and boron on leaf mineral composition, yield and fruit storability of balady mandarin trees . J Agric . Sci., Mansoura Univ., 28 (9) : 6911 - 6926.

El-Kassas S. E., Mahmoud H.M. and El- Shazly S.M. (1987) : Effect of certain micronutrients on the yield and fruit quality of Balady Mandarin . Journal of Agric. Sci. Vol. $18: 4$, 1987.

EL-Saida S.A.G (1996). Physiological studies on nutrition citrus . Ph. D. Thesis Fac. of Agric ., Menofiya University, Egypt .

El-Saida S.A.G.( 2001) : Effect of some growth regulators and Zinc sulphate treatments on yields and fruit quality of Washington navel orange . Annals of Agric. Sc., Moshtohor, Vol 39(2) : 1199-1212.

El-Shafey Y. H., Abd El Rahman A. M. and El Azaze , A.M. (2002 ): Effect of foliar application with calcium on yield and fruit quality of Valencia orange trees . Bull. Fac. Agric ., Cairo Univ., 53 (2002) : 275-288 .

El-Shazly S. A., 1981 : Mineral element analysis of some citrus plants as affected by some foliar applications. Ph. D. Thesis ., Faculty of Agricultural Ain-Shams University .

El-Zeftawi B.M. and Dinsey R.T. (1983) . Evaluation of abscission chemicals in various combinations for loosening Valencia orange during regreening. J. Amer. Soc. Hort.Sci., 58 (1): $129-139$.

Evenhuis , B. and De Waard P.W. (1980). Principles and practices in plant analysis . FAO. Soil Bull., 39(1): 152-162 .

Faust M. (1989 ): Physiology of temperate zone fruit trees John Wiley \& Sons , Inc , USA.
Ferguson , I . B. ( 1988) . Calcium and the regulation of plant growth and senescence . Hort . Sci . Vol., 23(2) : 262-266.

Follett R.H ; Murphy L. S .and Donahue R. , (1981 ): Fertilizers and soil amendments. Prentic- Hall, Inc.U. S .A

Giffillan I.M , Steveson J.A. and Koedemoer, W. (1974): Gibberellic acid reduces creasing in late - season navel . South African cooperative Citrus Exchange, Nel spruit citrus and sub - tropical fruit Jour . No . 482: 4-5.

Grierson D. and Tucker G.A. (1983) Timing of ethylene and polygalacturonase synthesis in relation to control of tomato fruit ripening planta $157: 174-221$.

IbraheimT. A. , Sayed R. A. and Salem. S.E. (2001) : Effect of chemical and hand thinning on regulating alternative bearing of Balady mandarin trees . Minia of Agric. Res. and development vol. (21) No. 2 , PP 235- 249 .

Kanonich Y., Erner, Y. Golds chmidt E.E. , and Goren, R. (2000) . Control of fruit number, size and quality in easy peeling Tangerine hybrid " Nova" using growth regulators. Abstract of the ninth Int. Soc. of Citriculture Congress. Orlando., Florida, U.S.A, P. 155.

Khadr A, A., Mougheith G. M. and El- Ashram , (1978): Influence of foliar application of some nutrient elements on growth, yield , fruit quality, and leaf mineral composition of Washington Navel orange trees annals of Agricultural Science Moshtohor 9, 138- 156.

Koch F.C. and Meekin, L.T. (1924): A new direct nesslerization micro - kjeldahl method a modification of the nessler-folin reagent for ammonia, J. Amer. Chem . Soc., 46 , 20662069

MengeL L .X and kirkby E.A. (1978).Principles of plant nutrition Inter. Potash Institute.pp.454455 Berne, Switzerland.

Meyer B. S., Anderson D. B., Bhning R. H. , (1966) : Introduction to plant physiol . D. van Nostr and Comp. Inc. New Jersey, USA, PP. 541 .

Miller E.V., Winston R. J. and Schomer A. H.. ( 1940) . Physiological studies of plastid pigments in rind of maturing oranges. Journal of Agriculture Research $60: 259-67$.

Mohsen M. A., Mehana A.S., El-Hefnawy M.S. and N. A. Sharaf ,1990 : Mineral composition of Balady orange leaves as influenced by foliar application of some micro - elements . Zagazig. J. Agric. Res. Vol., 17 No 3(8) 
Hamed N.A. M., (2005 ): Some Physiological studies on the nutrition of citrus . M.Sc. Agric. Sciences , Fac. of Agric., Cairo University .

Nawab Ali , Khnan Miskeen, Shah Mukamil, A.S. Husain and Amin Noorul, (1992) : Foliar application of iron, Zinc and manganese enhances vegetative growth of Citrus sinensis . Sarhad Journal of Agriculture 8 (1) 43- 48 . ( Hort. Abst. Vol., $63: 7118$ ).

Njaroge C.K. Kerbel, E. L. ,and Briskin ,D. P.( 1998 a) : Effect of calcium and calmodulin antagonists on ethylene biosynthesis in tomato fruit . J. Sci. food and Agric ., 76(2) : 209-214 (C. F. Hort. Abst., 68: 5095, 1998 )

Njaroge C.K. Kerbel , E. L. , and Briskin ,D. P.( 1998 b) : Effect of exogenous calmodulin and ATP on activity of ethylene forming enzyme obtained from tomatoes and green pea- pods J. Sci. food and Agric ., 76(2) : 215-220(C.F. Hort. Abst., 68 : 5096, 1998) .

Ouyang T., (1993) :Soil micronutries and citrus growth . Pedosphere 3(4) 341 - 347 . ( Hort. Abst. Vol. 65 : 1604 ).

Perveen, S. and Rehman, H. (2000). Effect of foliar application of zinc, manganese and boron in combination with urea on the yield of sweet orange. Pakistan J. of Agric. Res., 16 (2) : 135-141

Sayed R.A., Sabh A.Z. and Ibrahim A. I.,( 2004 a): Effect of calcium and gibberellic acid sprays on yield, quality and abscission of grapefruit . J. Agric. Sci. Mansoura Univ. , 29 (3) : 1239- 1255, 2004.

Sayed R.A., Solaiman B. M. and Abo- ElKomsan E.O.,( $2004 \mathrm{~b}$ ): Effect of foliar sprays of some mineral nutrients, GA3 and or Biostimulant on yield and fruit quality of Valencia orange trees grown in sandy soil . Egyptian Journal of Applied Sciences, 19 No. 5 . (222-238)

Sharaf A, N., ( 1990) . Effect of some micronutrients application on the productivity of Balady orange trees. Ms.c. Thesis, Facuity of Agricultur, Zagazig University .

Simit C. J. (1990 ) : Improving fruit set of navel orange trees Inligtings bulletin Institute, Vir citrus en substracipese Vrugte (1989). No . 202 :12-13 Nel spruit, South Africa (Hort . Abst , 60 : 5678).
Singh S, K and Sharma, R.R. (2000) Combating micronutrient deficiencies in Citrus crops .Ind . Hort. 8-11 .

Smit J. H. C and French C.S. ,(1963 ): The major and accessory pigments in photosynthesis. Ann. Rev. plant physiol., 14 : 181-224.

Snedecor G.W. and Cochran, W.G. ( 1967 ) : Statistical methods. Iowa State Univ, Press, Iowa. U.S.A.

Sourour M, M (2000) Effect of foliar application of some micronutrient forms on growth, yield, fruit quality and leaf mineral composition of Valencia orange trees grown in north Sinai Alex J of Agric Res., 45(1) : 269- 285.

Stino G.R. , Baker, S. I. Khattab M. M. and Gharbawy N.H. (1981 ) : Abscission zone formation of developing leconte pear fruits as affected by ethephon or NAA treatments . Egypt. J. Hort. 8, No. 1, PP. 25-31 (1981)

Swietlik D. and Laduke V. J.,(1991) :Productivity , growth and leaf mineral composition of orange and grapefruit trees foliar sprayed with Zinc and manganese . Journal of Plant Nutrition 14(2)129-142(Hort. Abst. Vol. 63: 1579.

Talon M. , Mehouachi J. and Eprimo -Millo (2000 ) : Manipulation of fruit set in citrus : Function and Effects of Gibberellins . ISC Congress, 3-7 December 2000 , Orlando, Florida, USA .

Thomas and Dutcher (1924) : The colorimetric determination of $\mathrm{CHO}$ in plant by the picric acid reduction method. Journal American Chem Society , $40.7-12$.

Wettstein's , D., (1957). Chlorophyll, letal and der Submikrosvopische formech Cell- der plastiden. Exptl. Cell. 12 : 427 - 433 .

Yagodin B.A. (1984 a): Agricultural chemistry Vol. 1 Mir. Publishers . Moscow . SSR .

Yagodin. B.A. (1984 b): Agricultural chemistry Vol. 2 Mir. Publishers . . Moscow . SSR .

Zacarias F.A. and Stead A.D (2000): Hormonal signals Regulating the Abscission-- process in citrus . ISC Congress ,3-7 December2000, Orlando, Florida, USA. 
استجابة اشجار برتقال الفالنشيا المنزرعة في الاراضى الرملية للمعاملة بالبايوزيم والامكوتون والإنون

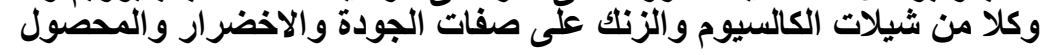

$$
\text { قسم الموالح - معهد بحوث البساتين - مركز البحوث الزر اعية ــ الجيزة الصياده }
$$

\section{ملخص}

اجريت هذه الدراسة خلال موسمى 2005/2004 ، 2006/2005 على اشجار برتقال فالنشيا عمر 14 سنة مطعومة

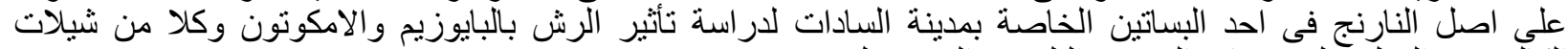

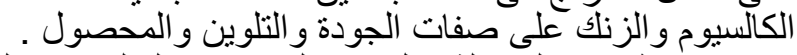

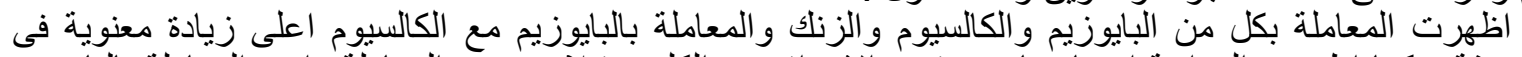

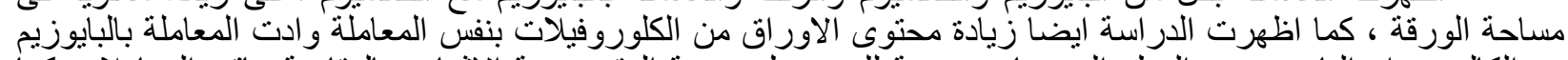

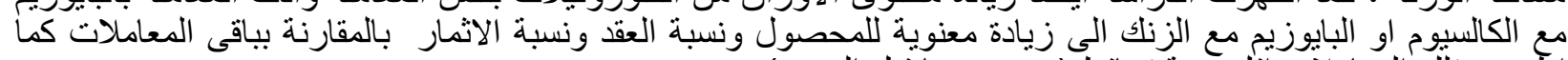

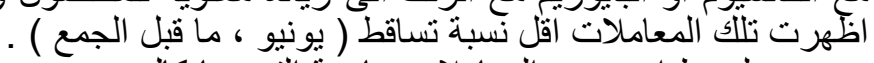

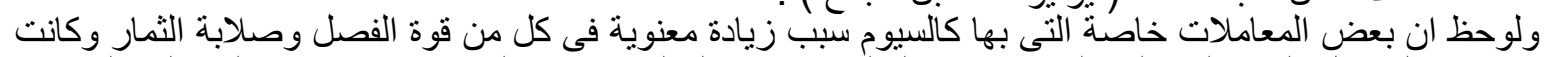

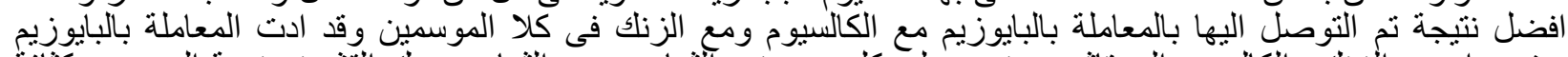

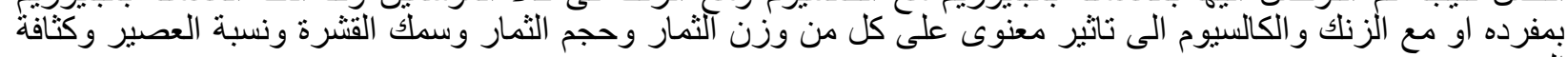

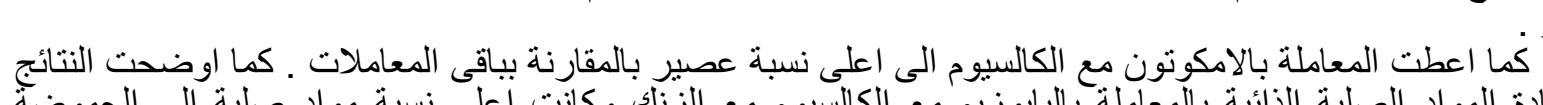
العصنير :

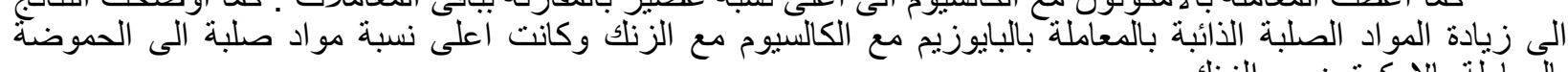

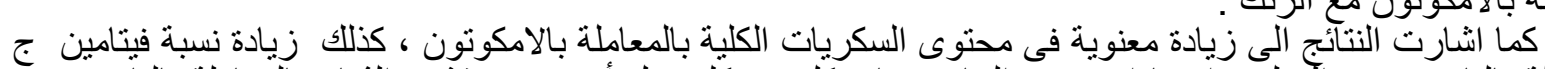

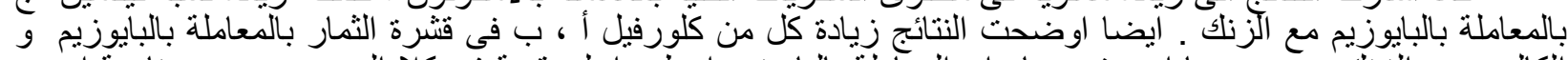

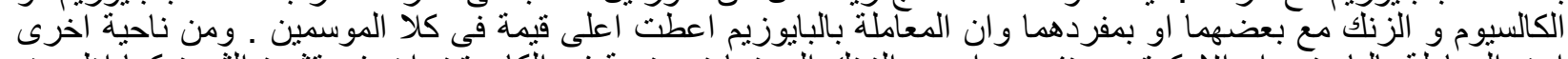

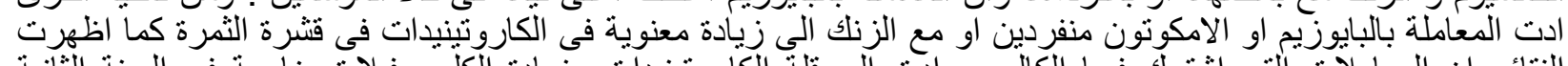

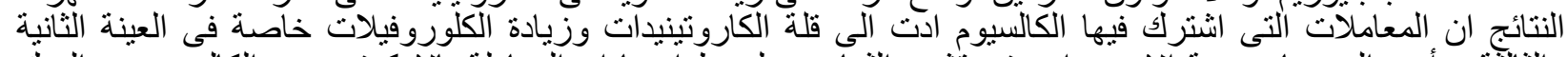

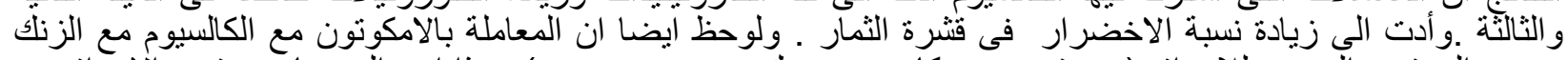

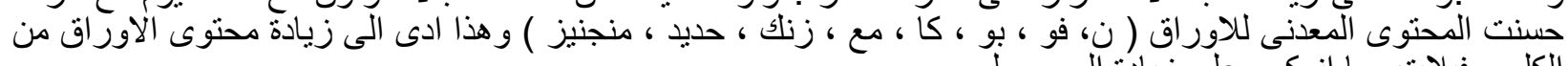

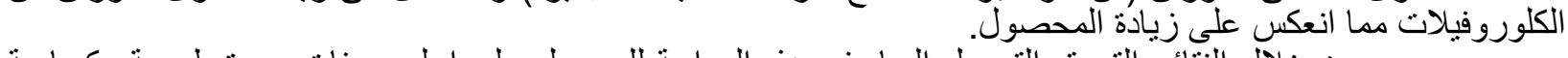

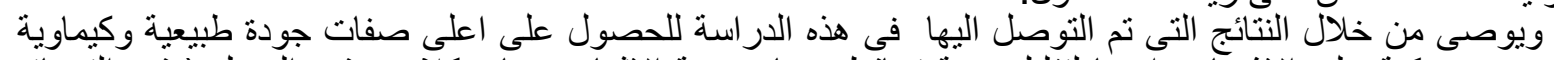

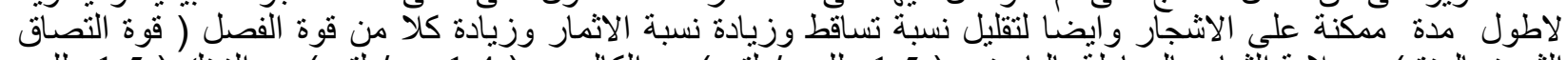

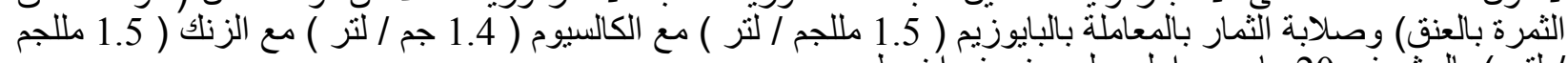

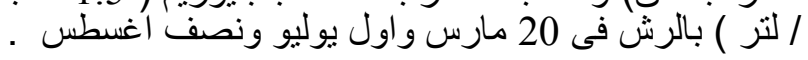

